\title{
Comparative analysis of antimicrobial resistance and genetic characteristics of Escherichia coli from broiler breeder farms in Korea
}

\author{
Shin-Woo Kim, Koeun Kim, and Young Ju Lee
}

\begin{abstract}
Broiler breeder farms could be a reservoir of Escherichia coli, disseminating antimicrobial resistance and virulence factors. We investigated the antimicrobial resistance of E. coli from nine broiler breeder farms and characterised their resistance and virulence genes. A total of $256 \mathrm{E}$. coli showed a high level of resistance to tetracycline, nalidixic acid, ampicillin, and cephalothin, followed by trimethoprim-sulfamethoxazole and chloramphenicol. The resistance to nalidixic acid, ampicillin, trimethoprim-sulfamethoxazole, and chloramphenicol showed significant differences among the farms. Among $202 \beta$-lactam-resistant E. coli, 138 carried $\beta$-lactamase genes. The most prevalent $\beta$-lactamase gene was $b l a_{\text {TEM-1 }}$, of which the presence differed significantly across the farms. Out of 197 tetracycline-resistant E. coli isolates, tet $A$ and tetB were detected in 164 and 50, with significant differences among the farms. Also, 45 of 196 nalidixic acid-resistant E. coli carried qnrS, whereas 67 of 149 trimethoprimsulfamethoxazole-resistant $E$. coli carried sul2. Among the five virulence genes tested, omp $T$ was the most prevalent, and all genes except for iutA distributed significantly different among the farms. The phenotypic and genotypic characteristics of E. coli were significantly different among the farms; therefore, management at the breeder level is required to control the vertical transmission of E. coli.
\end{abstract}

Key words: Escherichia coli, poultry, broiler parent stock, antimicrobial resistance, virulence gene.

Résumé : Les élevages de reproduction de poulets à griller pourraient être des réservoirs d’Escherichia coli, propageant la résistance aux antimicrobiens et les facteurs de virulence. Nous avons étudié la résistance aux antimicrobiens d'E. coli provenant de neuf élevages de reproduction des poulets à griller et avons caractérisé leurs gènes de résistance et de virulence. Un total de 256 E. coli ont montré un fort taux de résistance à la tétracycline, l'acide nalidixique, à l'ampicilline, et la céphalothine, suivi de triméthoprime-sulfaméthoxazole et le chloramphénicol. La résistance à l'acide nalidixique, l'ampicilline, la triméthoprime-sulfaméthoxazole, et le chloramphénicol ont montré des différences significatives entre les fermes. Parmi les $202 \mathrm{E}$. coli résistantes aux $\beta$ lactames, 138 portaient les gènes de la $\beta$ lactamase. Le gène de $\beta$ lactamase la plus prévalente était $b l a_{\mathrm{TEM}-1}$, et sa présence différait significativement à travers toutes les fermes. Parmi les 197 isolats d'E. coli résistances à la tétracycline, les gènes tetA et tetB ont été détectés dans 164 et 50, avec des différences significatives entre les fermes. Aussi, 45 des $196 \mathrm{E}$. coli résistantes à l'acide nalidixique portaient le gène qnrS tandis que 67 des $149 \mathrm{E}$. coli résistantes à la triméthoprime-sulfaméthoxazole-portaient le gène sul2. Parmi les cinq gènes de virulence testés, le gène ompT était le plus prévalent, et tous les gènes, sauf iutA, étaient distribués de façon significativement différente dans les fermes. Les caractéristiques phénotypiques et génotypiques d'E. coli étaient significativement différentes entre les fermes; donc une gestion à l'échelle du reproducteur est requise afin de contrôler la transmission verticale d'E. coli. [Traduit par la Rédaction]

Mots-clés : Escherichia coli, volaille, cheptels parentaux des poulets à griller, résistance aux antimicrobiens, gène de virulence.

Received 7 September 2021. Accepted 2 January 2022.

S.-W. Kim,* K. Kim,* and Y.J Lee. College of Veterinary Medicine \& Zoonoses Research Institute, Kyungpook National University, Daegu 41566, Republic of Korea.

Corresponding author: Young Ju Lee (email: youngju@knu.ac.kr).

*These authors contributed equally to this work.

(C) 2022 The Author(s). This work is licensed under a Creative Commons Attribution 4.0 International License (CC BY 4.0), which permits unrestricted use, distribution, and reproduction in any medium, provided the original author(s) and source are credited. 


\section{Introduction}

Escherichia coli is a Gram-negative bacterium that commensally inhabits the intestinal tract of animals, including humans, and it is commonly found in farm environments because of inadequate sanitation and poor fecal-sludge management (Jang et al. 2017). Although most strains of E. coli are harmless, antimicrobial-resistant E. coli and their resistance genes can be shared by several species of animals and humans through the food chain, creating a public health concern (Szmolka and Nagy 2013; Florez-Cuadrado et al. 2018; Poirel et al. 2018). Critically important antimicrobials in human medicine, as classified by World Health Organization (2018), are frequently used to prevent, control, or treat disease in Korean poultry stocks (APQA 2020); therefore, antimicrobial-resistant E. coli from poultry is considered a serious risk to human health (Florez-Cuadrado et al. 2018; Kim et al. 2020).

The broiler production chain has a pyramidal structure comprising the grandparent stock and parent stock (PS) on top, the commercial broiler chickens in the middle, and processing at the bottom. Therefore, antimicrobialresistant bacteria in poultry-breeding pyramid are easily disseminated in the broiler chicken farms and chicken slaughterhouses via the fecal-oral route (Petersen et al. 2006; Nilsson et al. 2014). Moreover, Dierikx et al. (2013) and Apostolakos et al. (2019) have already reported that extended-spectrum $\beta$-lactamase (ESBL) or plasmidmediated AmpC $\beta$-lactamase-producing E. coli in the broiler PS was substantially transferred to subsequent production levels.

The antimicrobial resistance of E. coli from commercial broiler chicken farms, chicken meat, and eggs has been consistently reported worldwide (Musgrove et al. 2006; Mohamed et al. 2014; Sary et al. 2019; Parvin et al. 2020); however, the resistance at the PS stage has not been fully studied. Therefore, we investigated the antimicrobial resistance of commensal E. coli from nine PS farms and compared the characteristics of their resistance and virulence genes.

\section{Materials and Methods}

This study was performed with E. coli isolated from environment sampling; therefore, no ethical statement is required.

\section{Bacterial strains}

Feces and dust samples were periodically collected from 74 flocks of nine broiler PS farms of a single company in Korea. Details of the number of flocks tested, and the number of isolates examined is provided in Table 1. Escherichia coli was isolated following the standards set by the "National Poultry Improvement Plan" (USDA 2014). Briefly, 15 random areas per flock were swabbed with sterile gauze swab which was moistened with skim milk (Fluka, Neu-Ulm, Germany). About $10 \mathrm{~g}$ of each dust or fecal sample was collected with

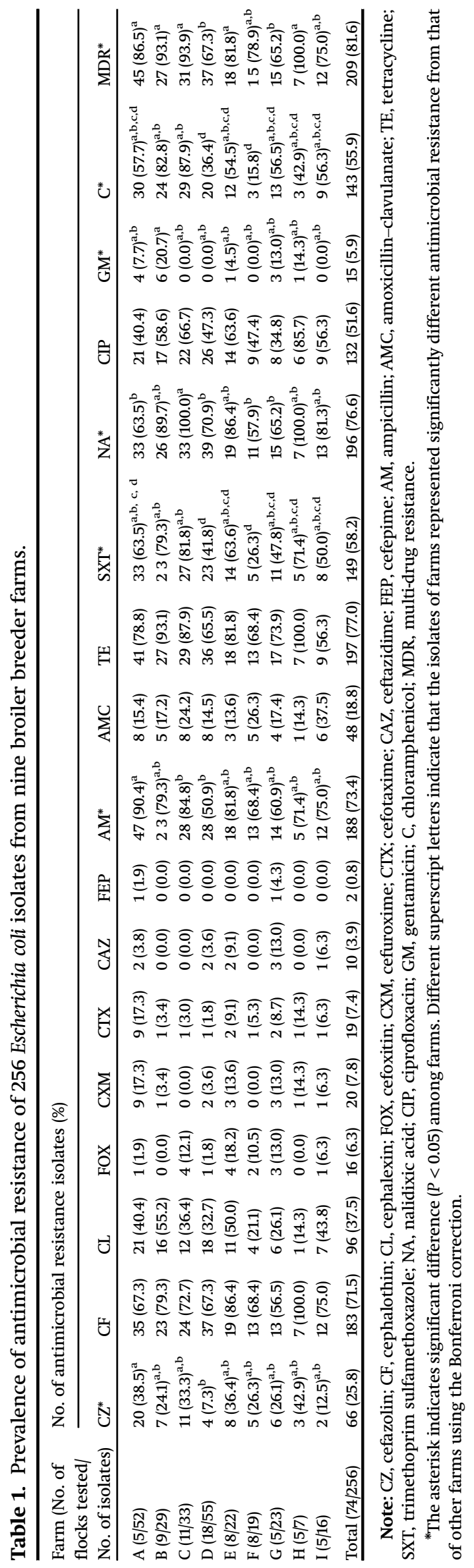

- Published by Canadian Science Publishing 
different gauze swabs and transported to laboratory in sterile whirl pack. The samples are enriched in tryptic soy broth (BD biosciences, Sparks, MD, USA) and then streaked on MacConkey agar (BD Biosciences, Sparks, MD, USA). The suspected E. coli colonies were confirmed using polymerase chain reaction (PCR) using AccuPrep Genomic DNA Extraction Kit (Bioneer, Daejeon, Korea) and AccuPower ${ }^{\circledR}$ PCR PreMix \& Master Mix (Bioneer, Daejeon, Korea) described by Candrian et al. (1991), using TaKaRa PCR Thermal Cycler Dice (TaKaRa, Seoul, Korea). If the isolates from the same farm showed an identical antimicrobial susceptibility pattern, one of the isolates was randomly selected. A total of $256 \mathrm{E}$. coli isolates were included in this study.

\section{Antimicrobial susceptibility testing}

The disk diffusion method was used to investigate the antimicrobial susceptibility of all $\mathrm{E}$. coli isolates based on the Clinical and Laboratory Standards Institute (2018). The antimicrobials were chosen based on their importance to both broiler breeder industry and human health. The antimicrobial agents (BD Biosciences, San Jose, CA, USA) used in this study were as follows: amoxicillin-clavulanate $(20 / 10 \mu \mathrm{g})$; ampicillin $(10 \mu \mathrm{g})$; cefazoline (30 $\mu \mathrm{g})$; cefepime $(30 \mu \mathrm{g})$; cefotaxime $(30 \mu \mathrm{g})$; cefoxitin $(30 \mu \mathrm{g})$; ceftazidime (30 $\mu \mathrm{g})$; cefuroxime (30 $\mu \mathrm{g})$; cephalexin $(30 \mu \mathrm{g})$; cephalothin (30 $\mu \mathrm{g})$; chloramphenicol (30 $\mu \mathrm{g})$; ciprofloxacin (5 $\mu \mathrm{g})$; gentamicin $(10 \mu \mathrm{g})$; nalidixic acid (30 $\mu \mathrm{g})$; tetracycline (30 $\mu \mathrm{g})$; and trimethoprim-sulfamethoxazole (1.25/23.75 $\mu \mathrm{g})$. Multidrug resistance (MDR) was defined as resistance to at least one agent of three or more antimicrobial classes (Magiorakos et al. 2012). Escherichia coli ATCC 25922 served as a quality control strain.

\section{Detection of antimicrobial resistance and virulence genes}

The primers (Bioneer, Daejeon, Korea) used to detect the antimicrobial resistance and virulence genes are listed in Table 2 . The antimicrobial resistance genes investigated in this study confer resistance to $\beta$-lactams $\left(b l a_{\mathrm{TEM}}, b l a_{\mathrm{SHV}}, b l a_{\mathrm{OXA}}\right.$, and $\left.b l a_{\mathrm{CTX}}\right)$, aminoglycosides [aac(6')-Ib, aac(3)-II, and ant(2')-I], plasmid-mediated quinolones ( $q n r A, q n r B, q n r D, q n r S$, and qepA), tetracyclines (tet $A$, tet $B$, and tetC), sulfonamides (sul1 and sul2), and chloramphenicols (catA1 and $c m l A$ ). Moreover, the amplicons of the $\beta$-lactamase genes were sequenced using an automatic sequencer (Cosmogenetech, Daejeon, Korea), and the sequences were compared with sequences in a nucleotide database through the Basic Local Alignment Search Tool from the National Center for Biotechnology Information (https://blast.ncbi.nlm.nih.gov/Blast.cgi). The five virulence genes (iroN, ompT, iss, iutA, and hylF), which are minimal predictors of avian pathogenic E. coli, were also identified by PCR amplification (Johnson et al. 2008).

\section{Statistical analysis}

Statistical analysis was performed using SPSS25 software (IBM Corp., Armonk, NY, USA). Pearson's chi-square test was used to confirm the significant difference $(P<0.05)$ of antimicrobial resistance and virulence genes among the farms. Bonferroni correction was used to account for the variation in the numbers of flocks and isolates across the farms.

\section{Results}

Antimicrobial resistance profiles

The antimicrobial resistance profiles of the E. coli isolates from the nine broiler PS farms are shown in Table 1. A total of 256 E. coli showed a high resistance to tetracycline (77.0\%), nalidixic acid (76.6\%), ampicillin (73.4\%), and cephalothin (71.5\%), followed by trimethoprim-sulfamethoxazole (58.2\%) and chloramphenicol (55.9\%). Although the prevalence of tetracycline and cephalothin resistance was not significantly different among the farms, that of nalidixic acid, ampicillin, trimethoprim-sulfamethoxazole, and chloramphenicol resistance was significantly different, ranging from $57.9 \%$ to $100 \%, 50.9 \%$ to $90.4 \%, 26.3 \%$ to $81.8 \%$, and $36.4 \%$ to $87.9 \%$, respectively $(P<0.05)$. The prevalence of cefazoline and gentamicin resistance was only $25.8 \%$ and $5.9 \%$, respectively, but their prevalence also showed significant difference among the farms, ranging from $7.3 \%$ to $42.9 \%$ and $0 \%$ to $20.7 \%$, respectively $(P<0.05)$. Regarding cephalosporin resistance, $E$. coli showed a higher resistance to first-generation cephalosporins (cephalothin, 71.5\%; cephalexin, 37.5\%; and cefazoline, $25.8 \%$ ) but a lower resistance to second (cefuroxime, 7.8\%; cefoxitin, 6.3\%)-, third (cefotaxime, 7.4\%; ceftazidime, 3.9\%)-, and fourth (cefepime, $\mathbf{0 . 8 \%}$ )-generation cephalosporins. Cefepime-resistant E. coli were only present in two of the nine PS farms. Interestingly, 209 (81.6\%) E. coli isolates were classified as having MDR, and the prevalence of MDR strains was significantly different among the nine farms $(P<0.05)$.

\section{Distribution of antimicrobial resistance genes}

The distribution of the antimicrobial resistance genes in the $256 \mathrm{E}$. coli isolates from the nine broiler PS farms is represented in Fig. 1. A total of 202 (78.9\%) E. coli isolates were resistant to $\beta$-lactam antimicrobials and $138(68.3 \%)$ carried the $\beta$-lactamase gene. $b l a_{\text {TEM- }}$ was the most prevalent (132 isolates, 65.3\%), but its prevalence was significantly different among the farms, ranging from $46.5 \%$ to $84.6 \%(P<0.05)$. $b_{\text {CTX-M-1 }}$ (six isolates, $3.0 \%$ ), bla $a_{\text {TEM-135 }}$ (three isolates, $1.5 \%$ ), bla $a_{\text {СТХ-M-55 }}$ (two isolates, $1.0 \%$ ), and $b l a_{\text {TEM-176 }}$ (one isolate, $0.5 \%$ ) showed low prevalence, and no significant differences among the farms. However, E. coli isolates from farm A carried all five genes: $b l a_{\text {TEM-1 }}, b l a_{\text {TEM-135, }}, b l a_{\text {TEM-176, }}$ $b l a_{\mathrm{CTX}-\mathrm{M}-1}$, and $b l a_{\mathrm{CTX}-\mathrm{M}-55}$.

Among the 196 quinolone-resistant E. coli isolates, $45(23.0 \%)$ carried the $q n r S$ gene, followed by $q n r B$ (8 isolates, $4.1 \%$ ) and $q n r A$ ( 1 isolate, $0.5 \%)$. None of the E. coli isolates carried qnrD or qepA. Among the 143 (55.9\%) chloramphenicol-resistant E. coli isolates, cmlA 
Table 2. Primers used in this study.

\begin{tabular}{|c|c|c|c|}
\hline Target gene & Sequence (5'-3') & $\begin{array}{l}\text { Size } \\
\text { (bp) }\end{array}$ & Reference \\
\hline \multicolumn{4}{|l|}{ Virulence genes } \\
\hline iroN & $\begin{array}{l}\text { F: AATCCGGCAAAGAGACGAACCGCCT } \\
\text { R: GTTCGGGCAACCCCTGCTTTGACTTT }\end{array}$ & 553 & Johnson et al. (2008) \\
\hline ompT & $\begin{array}{l}\text { F: TCATCCCGGAAGCCTCCCTCACTACTAT } \\
\text { R: TAGCGTTTGCTGCACTGGCTTCTGATAC }\end{array}$ & 496 & Johnson et al. (2008) \\
\hline hlyF & $\begin{array}{l}\text { F: GGCCACAGTCGTTTAGGGTGCTTACC } \\
\text { R: GGCGGTTTAGGCATTCCGATACTCAG }\end{array}$ & 450 & Johnson et al. (2008) \\
\hline iss & $\begin{array}{l}\text { F: CAGCAACCCGAACCACTTGATG } \\
\text { R: AGCATTGCCAGAGCGGCAGAA }\end{array}$ & 323 & Johnson et al. (2008) \\
\hline iutA & $\begin{array}{l}\text { F: GGCTGGACATCATGGGAACTGG } \\
\text { R: CGTCGGGAACGGGTAGAATCG }\end{array}$ & 302 & Johnson et al. (2008) \\
\hline \multicolumn{4}{|l|}{$\beta$-lactamases ${ }^{a}$} \\
\hline TEM & $\begin{array}{l}\text { F: CATTTCCGTGTCGCCCTTATTC } \\
\text { R: CGTTCATCCATAGTTGCCTGAC }\end{array}$ & 800 & Dallenne et al. (2010) \\
\hline SHV & $\begin{array}{l}\text { F: CACTCAAGGATGTATTGTG } \\
\text { R: TTAGCGTTGCCAGTGCTCG }\end{array}$ & 885 & Briñas et al. (2002) \\
\hline OXA & $\begin{array}{l}\text { F: TTCAAGCCAAAGGCACGATAG } \\
\text { R: TCCGAGTTGACTGCCGGGTTG }\end{array}$ & 702 & Briñas et al. (2002) \\
\hline CTX-M group I & $\begin{array}{l}\text { F: GACGATGTCACTGGCTGAGC } \\
\text { R: AGCCGCCGACGCTAATACA }\end{array}$ & 499 & Pitout et al. (2004) \\
\hline CTX-M group II & $\begin{array}{l}\text { F: GCGACCTGGTTAACTACAATCC } \\
\text { R: CGGTAGTATTGCCCTTAAGCC }\end{array}$ & 351 & Pitout et al. (2004) \\
\hline CTX-M group III & $\begin{array}{l}\text { F: CGCTTTGCCATGTGCAGCACC } \\
\text { R: GCTCAGTACGATCGAGCC }\end{array}$ & 307 & Pitout et al. (2004) \\
\hline CTX-M group IV & $\begin{array}{l}\text { F: GCTGGAGAAAAGCAGCGGAG } \\
\text { R: GTAAGCTGACGCAACGTCTG }\end{array}$ & 474 & Pitout et al. (2004) \\
\hline \multicolumn{4}{|c|}{ Aminoglycoside modifying enzymes } \\
\hline $\operatorname{aac}\left(6^{\prime}\right)-I b$ & $\begin{array}{l}\text { F: TGACCTTGCGATGCTCTATG } \\
\text { R: TTAGGCATCACTGCGTGTTC }\end{array}$ & 508 & Jiang et al. (2008) \\
\hline $\operatorname{aac}(3)-I I$ & $\begin{array}{l}\text { F: TGAAACGCTGACGGAGCCTC } \\
\text { R: GTCGAACAGGTAGCACTGAG }\end{array}$ & 369 & Sandvang and Aarestrup (2000) \\
\hline $\operatorname{ant}(2 ”)-I$ & $\begin{array}{l}\text { F: GGGCGCGTCATGGAGGAGTT } \\
\text { R: TATCGCGACCTGAAAGCGGC }\end{array}$ & 740 & Sandvang and Aarestrup (2000) \\
\hline \multicolumn{4}{|c|}{ Plasmid-mediated quinolone } \\
\hline$q n r A$ & $\begin{array}{l}\text { F: TCAGCAAGAGGATTTCTCA } \\
\text { R: GGCAGCACTATTACTCCCA }\end{array}$ & 627 & Wang et al. (2003) \\
\hline$q n r B$ & $\begin{array}{l}\text { F: CGACCTGAGCGGCACTGAAT } \\
\text { R: TGAGCAACGATGCCTGGTAG }\end{array}$ & 515 & Jiang et al. (2008) \\
\hline$q \eta r D$ & $\begin{array}{l}\text { F: CGAGATCAATTTACGGGGAATA } \\
\text { R: AACAAGCTGAAGCGCCTG }\end{array}$ & 582 & Cavaco et al. (2007) \\
\hline$q n r S$ & $\begin{array}{l}\text { F: ACCTTCACCGCTTGCACATT } \\
\text { R: CCAGTGCTTCGAGAATCAGT }\end{array}$ & 571 & Jiang et al. (2008) \\
\hline qepA & $\begin{array}{l}\text { F: CGTGTTGCTGGAGTTCTTC } \\
\text { R: CTGCAGGTACTGCGTCATG }\end{array}$ & 403 & Minarini et al. (2008) \\
\hline \multicolumn{4}{|l|}{ Tetracyclines } \\
\hline tetA & $\begin{array}{l}\text { F: GTAATTCTGAGCACTGTCGC } \\
\text { R: CTGCCTGGACAACATTGCTT }\end{array}$ & 956 & Sengeløv et al. (2003) \\
\hline tetB & $\begin{array}{l}\text { F: CTCAGTATTCCAAGCCTTTG } \\
\text { R: ACTCCCCTGAGCTTGAGGGG }\end{array}$ & 414 & Sengeløv et al. (2003) \\
\hline tetC & $\begin{array}{l}\text { F: CCTCTTGCGGGATATCGTCC } \\
\text { R: GGTTGAAGGCTCTCAAGGGC }\end{array}$ & 505 & Sengeløv et al. (2003) \\
\hline \multicolumn{4}{|l|}{ Sulfonamide } \\
\hline sul1 & $\begin{array}{l}\text { F: CTTCGATGAGAGCCGGCGGC } \\
\text { R: GCAAGGCGGAAACCCGCGCC }\end{array}$ & 433 & Sandvang et al. (1998) \\
\hline sul2 & $\begin{array}{l}\text { F: CGGCATCGTCAACATAACC } \\
\text { R: GTGTGCGGATGAAGTCAG }\end{array}$ & 720 & Maynard et al. (2003) \\
\hline
\end{tabular}


Table 2. (concluded).

\begin{tabular}{llcl}
\hline & & Size & \\
Target gene & Sequence $\left(5^{\prime}-3^{\prime}\right)$ & $(\mathrm{bp})$ & Reference \\
\hline $\begin{array}{l}\text { Chloramphenicol } \\
\text { catA1 }\end{array}$ & $\begin{array}{l}\text { F: AGTTGCTCAATGTACCTATAACC } \\
\text { R: TTGTAATTATTAAGCATTCTGCC }\end{array}$ & 547 & Van et al. (2008) \\
cmlA & $\begin{array}{l}\text { F: CCGCCACGGTGTTGTTTTATC } \\
\text { R: CACCTTGCCTGCCCATCATTAG }\end{array}$ & 698 & Van et al. (2008) \\
\hline
\end{tabular}

${ }^{a}$ Amplicons of $\beta$-lactamase genes were used for sequencing.

and catA1 were detected in 20 (14.0\%) and 14 (9.8\%) isolates, respectively.

Only $15 \mathrm{E}$. coli isolates showed resistance to gentamicin, and $a a c\left(6^{\prime}\right)-I b$ and $a a c(3)-I I$ were detected in $1(6.7 \%)$ isolate and $3(20.0 \%)$ isolates, respectively. However, E. coli from only farm A carried both these genes. None of the E. coli isolates carried ant(2')-I. Among the 197 tetracycline-resistant $E$. coli isolates, tetA, tetB, and tetC were detected in 164 (83.2\%), 50 (25.4\%), and 47 (23.9\%) isolates, respectively, and the prevalence of each gene was significantly different among the farms, ranging from $30.8 \%$ to $100 \%, 16.7 \%$ to $76.9 \%$, and $7.4 \%$ to $85.7 \%$, respectively $(P<0.05)$. Among the 149 sulfonamideresistant E. coli isolates, sul1 and sul2 were detected in $20(13.4 \%)$ and $67(45.0 \%)$ isolates, respectively, and the prevalence of only sul2 was significantly different among the farms, ranging from $20.0 \%$ to $81.8 \%(P<0.05)$.

\section{Distribution of virulence genes}

The distribution of the virulence genes in the $256 \mathrm{E}$. coli isolates from the nine broiler PS farms is shown in Table 3. Among the five virulence genes tested, ompT (67 isolates, $26.0 \%$ ) was the most prevalent, followed by hylF (65 isolates, $25.2 \%$ ), iroN (57 isolates, $22.1 \%$ ), iutA (50 isolates, 19.4\%), and iss (45 isolates, 17.4\%). iutA showed no significant differences among the farms, but the prevalence of ompT, hylF, iroN, and iss showed significant differences, ranging from $0 \%$ to $54.5 \%$, $0 \%$ to $45.5 \%$, $0 \%$ to $54.5 \%$, and $0 \%$ to $42.4 \%$, respectively $(P<0.05)$. Escherichia coli from farm $C$ showed a significantly high prevalence of four virulence genes $(42.4 \%-54.5 \%)$, except iutA, whereas E. coli from farm G showed a significantly low prevalence $(0 \%-8.7 \%)(P<0.05)$. However, E. coli isolates from farm $\mathrm{H}$ did not carry any of these genes.

\section{Discussion}

The broiler chicken production system is linked from the beginning to end because of its pyramidal structure; therefore, the control of disease and of antimicrobialresistant bacteria at each level is crucial to prevent vertical transmission (Petersen et al. 2006; Nilsson et al. 2014). Antimicrobial resistance arises as a direct consequence of the excessive use of antimicrobials in livestock including poultry, and approximately $1000 \mathrm{t}$ of antimicrobials were annually sold from 2011 to 2019 in Korea's livestock industry (APQA 2020). Owing to the massive amount of antimicrobials used in the poultry industry, antimicrobial resistance in broiler breeding chickens can directly reflect the dissemination to their offspring through hatcheries, which serve as a reservoir of antimicrobialresistant isolates (Osman et al. 2018).

In this study, E. coli isolates from nine broiler PS farms showed a high resistance to tetracycline $(77.0 \%)$, nalidixic acid (76.6\%), ampicillin (73.4\%), and cephalothin (71.5\%). In particular, resistance to tetracycline and cephalothin was highly prevalent, with no significant difference among the PS farms. Although since 2013, veterinary prescriptions are required for the administration of various antimicrobials in Korea (MAFRA 2013), tetracycline is frequently used in poultry because of relatively cheap and effective treatment against a wide range of bacterial infection (Landoni and Albarellos 2015). However, the prevalence of nalidixic acid- and ampicillin-resistant E. coli was significantly different among the farms. Nalidixic acid was widely used before fluoroquinolones, which are known for their low toxicity and broad-spectrum applications, and were introduced in the 1980s (Emmerson and Jones 2003). Although the prevalence of ciprofloxacinresistant isolates showed no significant difference among the farms in this study, the presence of resistance to nalidixic acid is known to indicate an increased ciprofloxacin minimum inhibitory concentration (Kumar et al. 2009). The manufacturing and import of ciprofloxacin have been banned since 2008 in Korea, but enrofloxacin, which is metabolized to ciprofloxacin, has been approved for use in poultry (Ku et al. 2011; Seo and Lee 2020). Fluoroquinolones are classed as critical antimicrobials both in human (WHO 2018) and veterinary (OIE 2018) medicine; moreover, the US Food and Drug Administration has banned the use of fluoroquinolones in the poultry industry (FDA 2005). Ciprofloxacin resistance has increased in broiler breeder farms in Korea because of enrofloxacin use (APQA 2020), although a significant difference may be noted among the farms. Ampicillin is also effective in treating bacterial infections with its broad-spectrum activity in poultry (Roth et al. 2019). Therefore, breeder farms with a high resistance to ampicillin might have experienced more disease outbreaks.

Recently, the emergence and spread of antimicrobial resistance genes have raised serious public health 
Fig. 1. Distribution of genes related with resistance to $\beta$-lactam (A), quinolones and chloramphenicol (B), aminoglycoside, tetracyclines, and sulfonamide $(C)$ in Escherichia coli isolates from nine broiler breeder farms (A to I). The number of E. coli isolates shown resistance to each antimicrobial is in parentheses. ${ }^{*} P<0.05$.

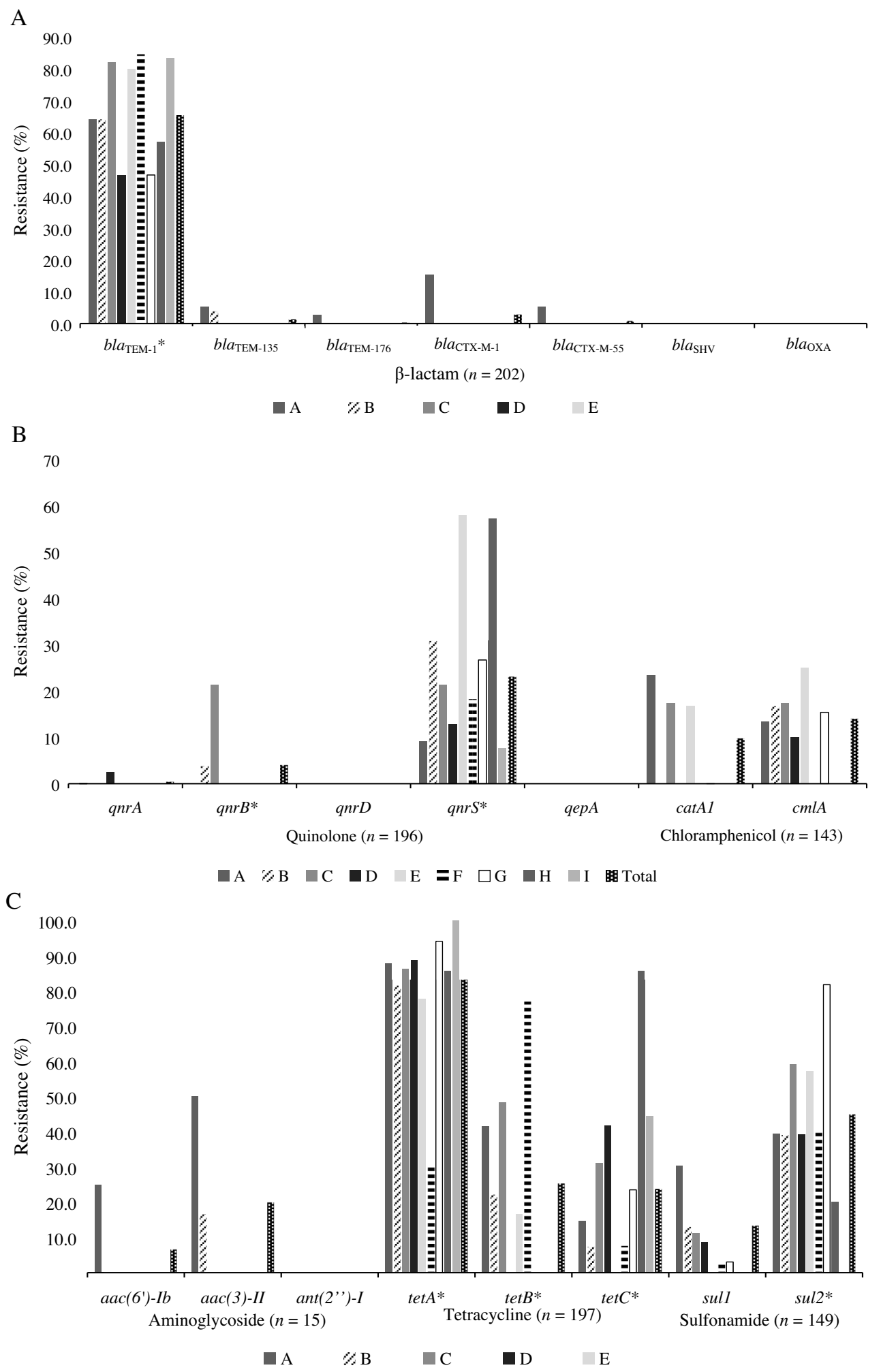

concerns (Szmolka and Nagy 2013). Generally, antimicrobial resistance spreads through vertical transmission, which involves the replication of a mutation promoting antibiotic resistance, and horizontal gene transfer, which involves the exchange of genetic material via the direct transfer of resistance genes (Poirel et al. 2018). 
Table 3. Distribution of virulence genes in 256 Escherichia coli isolates from nine broiler breeder farms.

\begin{tabular}{lllllll}
\hline \multirow{2}{*}{$\begin{array}{l}\text { No. of } \\
\text { Farm }\end{array}$} & \multicolumn{5}{l}{ No. of isolates with target virulence genes (\%) } \\
\cline { 3 - 7 } & isolates & IroN $^{a}$ & ompT $^{a}$ & $h l y F^{a}$ & $i^{a}$ & iutA \\
\hline A & 52 & $14(26.9)^{\mathrm{a}, \mathrm{b}}$ & $10(19.2)^{\mathrm{b}}$ & $10(19.2)^{\mathrm{a}, \mathrm{b}, \mathrm{c}, \mathrm{d}}$ & $8(15.4)^{\mathrm{a}, \mathrm{b}}$ & $13(25.0)$ \\
$\mathrm{B}$ & 29 & $9(31.0)^{\mathrm{a}, \mathrm{b}}$ & $11(37.9)^{\mathrm{a}, \mathrm{b}}$ & $12(41.4)^{\mathrm{a}, \mathrm{b}}$ & $9(31.0)^{\mathrm{a}, \mathrm{b}}$ & $12(41.4)$ \\
C & 33 & $18(54.5)^{\mathrm{a}}$ & $18(54.5)^{\mathrm{a}}$ & $15(45.5)^{\mathrm{b}, \mathrm{d}}$ & $14(42.4)^{\mathrm{a}}$ & $3(9.1)$ \\
D & 55 & $7(12.7)^{\mathrm{b}}$ & $11(20.0)^{\mathrm{b}}$ & $14(25.5)^{\mathrm{a}, \mathrm{b}, \mathrm{c}, \mathrm{d}}$ & $4(7.3)^{\mathrm{b}}$ & $11(20.0)$ \\
E & 22 & $5(22.7)^{\mathrm{a}, \mathrm{b}}$ & $7(31.8)^{\mathrm{a}, \mathrm{b}}$ & $4(18.2)^{\mathrm{a}, \mathrm{b}, \mathrm{c}, \mathrm{d}}$ & $7(31.8)^{\mathrm{a}, \mathrm{b}}$ & $2(9.1)$ \\
F & 19 & $2(10.5)^{\mathrm{b}}$ & $2(10.5)^{\mathrm{b}}$ & $4(21.1)^{\mathrm{a}, \mathrm{b}, \mathrm{c}, \mathrm{d}}$ & $1(5.3)^{\mathrm{a}, \mathrm{b}}$ & $1(5.3)$ \\
G & 23 & $2(8.7)^{\mathrm{b}}$ & $2(8.7)^{\mathrm{b}}$ & $0(0.0)^{\mathrm{b}}$ & $2(8.7)^{\mathrm{b}}$ & $2(8.7)$ \\
H & 7 & $0(0.0)^{\mathrm{a}, \mathrm{b}}$ & $0(0.0)^{\mathrm{a}, \mathrm{b}}$ & $0(0.0)^{\mathrm{a}, \mathrm{b}, \mathrm{c}, \mathrm{d}}$ & $0(0.0)^{\mathrm{a}, \mathrm{b}}$ & $0(0.0)$ \\
I & 16 & $0(0.0)^{\mathrm{b}}$ & $6(37.5)^{\mathrm{a}, \mathrm{b}}$ & $6(37.5)^{\mathrm{a}, \mathrm{b}, \mathrm{c}, \mathrm{d}}$ & $0(0.0)^{\mathrm{b}}$ & $6(37.5)$ \\
Total & 256 & $57(22.1)$ & $67(26.0)$ & $65(25.2)$ & $45(17.4)$ & $50(19.4)$ \\
\hline
\end{tabular}

${ }^{a_{T}}$ The asterisk indicates significant difference $(P<0.05)$ among farms. Different superscript letters indicate that the isolates of farms represented significantly different ratios of the virulence gene from that of other farms using the Bonferroni correction.

$\beta$-lactamase provides resistance to $\beta$-lactam antibiotics such as penicillin derivatives and cephalosporins, and TEM-, SHV-, OXA-, and CTX-M-type $\beta$-lactamases are the most well-known antimicrobial resistance determinants (Ghafourian et al. 2015). TEM-1 is considered the most widespread enzyme that confers $\beta$-lactam antimicrobial resistance to E. coli (Ghafourian et al. 2015). In this study also, TEM-1 was the most prevalent (68.3\%) among $\beta$-lactam-resistant E. coli; however, the prevalence of TEM-1 was significantly different among the farms, ranging from $46.5 \%$ to $84.6 \%$. Moreover, to the best of our knowledge, this is the first report of $b l a_{\text {TEM-135 }}$ and $b l a_{\text {TEM-176 }}$ in E. coli originating from poultry in Korea, although these genes were detected only in farm A. $b l a_{\text {TEM-176 }}$ has been sporadically isolated from wild birds in many countries, which contributes to the spread of antimicrobial-resistant genes globally (Wang et al. 2017). CTX-M can inactivate the third- and fourthgeneration cephalosporins and induce an MDR phenotype with a coresistance to a variety of antimicrobial classes (Seo et al. 2019). In this study, $b l a_{\mathrm{CTX-M-1}}$ and $b l a_{\mathrm{CTX}-\mathrm{M}-55}$ were detected in six and two isolates, respectively, and these genes have already been confirmed in E. coli from not only wild birds (Wang et al. 2017) but also chickens worldwide, including Korea (Rao et al. 2014; Lukman et al. 2016; Park et al. 2019). Interestingly, isolates from farm A harbored all five of the genes detected in this study, $b l a_{\mathrm{TEM}-1}, b l a_{\mathrm{TEM}-135}, b l a_{\mathrm{TEM}-176}$, $b l a_{\mathrm{CTX}-\mathrm{M}-1}$, and $b l a_{\mathrm{CTX-M-55}}$, and the distribution of these resistance genes corresponded to a high phenotypic resistance to ampicillin (synthetic penicillin) and cefazoline (a first-generation cephalosporin).

The mechanisms of plasmid-mediated quinolone resistance involves Qnr proteins that prevent quinolones from targeting DNA, the antimicrobial modification of $a a c\left(6^{\prime}\right)-I b-c r$ acetyltransferase, and an efflux pump mediated by qepA (Jacoby et al. 2014). The qnr gene is known to confer a low-level resistance to fluoroquinolone in E. coli, but it has been often reported to be coassociated with genes encoding $\beta$-lactamases (Cavaco et al. 2007). In this study, qnrB and $q n r S$ were found in E. coli isolates, which is consistent with the finding of a previous report from Korea (Huang et al. 2009); the distribution of these genes was also significantly different among the farms in this study. Moreover, qnrA was found in E. coli isolates only from farm D. The diverse distribution of $q n r$ between the farms may result in a variety of resistance patterns.

Chloramphenicol resistance is expressed through the enzymatic inactivation by catA1 and the activation of an efflux system by cmlA (Poirel et al. 2018). In this study, cmlA was more often detected than catA1. Generally, cmlA is known to be located on transferable plasmids that confer MDR in E. coli (Poirel et al. 2018). Therefore, they can easily be disseminated by horizontal transfer in PS farms.

In this study, among 15 identified E. coli isolates, four from farm A and six from farm B showed gentamicin resistance. Moreover, the major aminoglycoside-modifying enzyme genes, $a a c\left(6^{\prime}\right)-I b$ and $a a c(3)-I I$, were detected in E. coli only from farms A and B.

The distribution of tetracycline-resistance genes was also significantly different among the farms in this study, although there was no difference in phenotypic tetracycline-resistance among the farms. Furthermore, tetA $(83.2 \%)$ was predominant, followed by tetB $(25.4 \%)$ and tetC (23.9\%), which corresponds to previous reports on the high prevalence of the tetA gene in E. coli from poultry (Seifi and Khoshbakht 2016; Jahantigh et al. 2020). However, E. coli from farm F showed a high prevalence of tetB, whereas the prevalence of tetA was remarkably low. Roberts (1996) reported that only one of the genes, tetA or tetB, was predominant among the tetracycline-resistant bacterial isolates because mutual complementary genes encode the same phenotype. 
The sulfonamide-resistance genes, sul1 and sul2, inhibit the folic acid synthesis pathway (Poirel et al. 2018). In this study, sul2 was identified more frequently than sul1, which is in line with the findings of previous studies (Guerra et al. 2003; Kim et al. 2020). However, sul1 is more important because it exists in a class 1 integron and can be easily transferred (Szmolka and Nagy 2013).

Johnson et al. (2008) reported that the five virulence genes, hylF, ompT, iroN, iss, and iutA, act as minimal markers of avian pathogenic E. coli. In addition, Ewers et al. (2009) reported that avian pathogenic E. coli and human extraintestinal pathogenic E. coli strains are linked; therefore, the screening for virulence genes in E. coli isolates may be helpful in identifying potential zoonotic pathogens in poultry farms. In this study, the distribution of four of the five virulence genes showed a significant difference among the farms; therefore, E. coli from broiler breeder farms could be a reservoir for the dissemination of virulence genes in the broiler pyramidal structure.

In conclusion, our findings indicate that the phenotypic and genotypic characteristics related to antimicrobial resistance and virulence factors were significantly different among the farms; moreover, continuous monitoring and improved management at the breeder level are necessary to control the vertical transmission of $E$. coli, which can pose serious public health threat.

\section{Competing interests statement}

The authors declare there are no competing interests.

\section{Contributors' statement}

S.K. was responsible for conceptualization, writing the original manuscript, the methodology of the study and formal analysis of the results. K.K. contribute in the conceptualization, methodology of the study, statistical analysis, writing the original manuscript and revision of the manuscript. Y.J.L contribute in the supervision of the study, funding acquisition and was a major contributor in writing and editing the final manuscript. All authors read and approved the final manuscript.

\section{Acknowledgements}

This work was supported by Korea Institute of Planning and Evaluation for Technology in Food, Agriculture, Forestry and Fisheries (IPET) through Agriculture, Food and Rural Affairs Research Center Support Program, funded by Ministry of Agriculture, Food and Rural Affairs (MAFRA) (716002-7).

\section{References}

Animal and Plant Quarantine Agency (APQA). 2020. National antimicrobial resistance monitoring program. APQA, Gimcheon, Republic of Korea.

Apostolakos, I., Mughini-Gras, L., Fasolato, L., and Piccirillo, A. 2019. Assessing the occurrence and transfer dynamics of ESBL/pAmpC-producing Escherichia coli across the broiler production pyramid. PLoS ONE, 14(5): e0217174. doi:10.1371/ journal.pone.0217174. PMID:31100096.

Briñas, L., Zarazaga, M., Sáenz, Y., Ruiz-Larrea, F., and Torres, C. 2002. $\beta$-lactamases in ampicillin-resistant Escherichia coli isolates from foods, humans, and healthy animals. Antimicrob. Agents Chemother. 46(10): 3156-3163. doi:10.1128/AAC.46.10. 3156-3163.2002. PMID:12234838.

Candrian, U., Furrer, B., Höfelein, C.H., Meyer, R., Jermini, M., and Lüthy, J. 1991. Detection of Escherichia coli and identification of enterotoxigenic strains by primer-directed enzymatic amplification of specific DNA sequences. Int. J. Food Microbiol. 12(4): 339-351. doi:10.1016/0168-1605(91)90148-I. PMID:1854602.

Cavaco, L.M., Hansen, D.S., Friis-Møller, A., Aarestrup, F.M., Hasman, H., and Frimodt-Møller, N. 2007. First detection of plasmid-mediated quinolone resistance ( $q n r A$ and $q n r S)$ in Escherichia coli strains isolated from humans in Scandinavia. J. Antimicrob. Chemother. doi:10.1093/jac/dkl554.

Clinical and Laboratory Standards Institute (CLSI). 2018. M100 performance standards for antimicrobial susceptibility testing, performance standards for antimicrobial susceptibility testing. CLSI, Wayne, PA.

Dallenne, C., Da Costa, A., Decré, D., Favier, C., and Arlet, G. 2010. Development of a set of multiplex PCR assays for the detection of genes encoding important $\beta$-lactamases in Enterobacteriaceae. J. Antimicrob. Chemother. 65(3): 490-495. doi:10.1093/jac/dkp498.

Dierikx, C.M., van der Goot, J.A., Smith, H.E., Kant, A., and Mevius, D.J. 2013. Presence of ESBL/AmpC -producing Escherichia coli in the broiler production pyramid: a descriptive study. PLoS ONE 8(11): e79005. doi:10.1371/journal.pone. 0079005. PMID:24244401.

Emmerson, A.M., and Jones, A.M. 2003. The quinolones: decades of development and use. J. Antimicrob. Chemother. 51(90001): 13-20. doi:10.1093/jac/dkg208.

Ewers, C., Antão, E.-M., Diehl, I., Philipp, H.-C., and Wieler, L.H. 2009. Intestine and environment of the chicken as reservoirs for extraintestinal pathogenic Escherichia coli strains with zoonotic potential. Appl. Environ. Microbiol. 75(1): 184-192. doi:10.1128/AEM.01324-08. PMID:18997030.

Florez-Cuadrado, D., Moreno, M.A., Ugarte-Ruíz, M., and Domínguez, L. 2018. Antimicrobial resistance in the food chain in the European union. Adv. Food Nutr. Res. 86: 115-136. doi:10.1016/bs.afnr.2018.04.004. PMID:30077219.

Food and Drug Administration (FDA). 2005. Animal drugs, feeds, and related products; enrofloxacin for poultry; withdrawal of approval of new animal drug application. [Online]. Available from https://www.fda.gov/animal-veterinary/recallswithdrawals/withdrawal-enrofloxacin-poultry.

Ghafourian, S., Sadeghifard, N., Soheili, S., and Sekawi, Z. 2015. Extended spectrum beta-lactamases: definition, classification and epidemiology. Curr. Issues Mol. Biol. 17: 11-22. doi:10.21775/cimb.017.011. PMID:24821872.

Guerra, B., Junker, E., Schroeter, A., Malorny, B., Lehmann, S., and Helmuth, R. 2003. Phenotypic and genotypic characterization of antimicrobial resistance in German Escherichia coli isolates from cattle, swine and poultry. J. Antimicrob. Chemother. 52(3): 489-492. doi:10.1093/jac/dkg362.

Huang, S.-Y., Dai, L., Xia, L.-N., Du, X.-D., Qi, Y.-H., Liu, H.-B., Wu, C.-M., and Shen, J.-Z. 2009. Increased prevalence of plasmid-mediated quinolone resistance determinants in chicken Escherichia coli isolates from 2001 to 2007. Foodborne Pathog. Dis. 6(10): 1203-1209. doi:10.1089/ fpd.2009.0348. PMID:19735206.

Jacoby, G.A., Strahilevitz, J., and Hooper, D.C. 2014. Plasmidmediated quinolone resistance. Microbiol. Spectr. 2(5): 47-57. doi:10.1128/microbiolspec.PLAS-0006-2013. 
Jahantigh, M., Samadi, K., Dizaji, R.E., and Salari, S. 2020. Antimicrobial resistance and prevalence of tetracycline resistance genes in Escherichia coli isolated from lesions of colibacillosis in broiler chickens in Sistan, Iran. BMC Vet. Res. 16(1): 267. doi:10.1186/s12917-020-02488-z. PMID:32746815.

Jang, J., Hur, H.-G., Sadowsky, M.J., Byappanahalli, M.N., Yan, T., and Ishii, S. 2017. Environmental Escherichia coli: ecology and public health implications-a review. J. Appl. Microbiol. 123(3): 570-581. doi:10.1111/jam.13468. PMID:28383815.

Jiang, Y., Zhou, Z., Qian, Y., Wei, Z., Yu, Y., Hu, S., and Li, L. 2008. Plasmid-mediated quinolone resistance determinants $q n r$ and $a a c\left(6^{\prime}\right)-I b$-cr in extended-spectrum $\beta$-lactamase-producing Escherichia coli and Klebsiella pneumoniae in China. J. Antimicrob. Chemother. 61(5): 1003-1006. doi:10.1093/jac/ dkn063.

Johnson, T.J., Wannemuehler, Y., Doetkott, C., Johnson, S.J., Rosenberger, S.C., and Nolan, L.K. 2008. Identification of minimal predictors of avian pathogenic Escherichia coli virulence for use as a rapid diagnostic tool. J. Clin. Microbiol. 46(12): 3987-3996. doi:10.1128/JCM.00816-08. PMID:18842938.

Kim, Y.B., Yoon, M.Y., Ha, J.S., Seo, K.W., Noh, E.B., Son, S.H., and Lee, Y.J. 2020. Molecular characterization of avian pathogenic Escherichia coli from broiler chickens with colibacillosis. Poult. Sci. Elsevier Inc., 99(2): 1088-1095. doi:10.1016/ j.psj.2019.10.047.

Ku, B.K., Kim, H.J., Lee, Y.J., Kim, Y.I., Choi, J.S., Park, M.Y., et al. 2011. Genetic characterization and antimicrobial susceptibility of Campylobacter spp. isolated from domestic and imported chicken meats and humans in Korea. Foodborne Pathog. Dis. 8(3): 381-386. doi:10.1089/fpd.2010.0680. PMID:21114425.

Kumar, Y., Sharma, A., and Mani, K.R. 2009. High level of resistance to nalidixic acid in Salmonella enterica serovar Typhi in Central India. J. Infect. Dev. Countries 3(6): 467-469. doi:10.3855/jidc.419. PMID:19762961.

Landoni, M.F., and Albarellos, G. 2015. The use of antimicrobial agents in broiler chickens. Vet. J. Elsevier Ltd, 205(1): 21-27. doi:10.1016/j.tvj1.2015.04.016.

Lukman, D.W., Sudarwanto, M.B., Purnawarman, T., Latif, H., Pisestyani, H., Sukmawinata, E., Akineden, Ö. et al. 2016. CTX-M-1 and CTX-M-55 Producing Escherichia coli Isolated from Broiler Feces in Poultry Slaughterhouse, Bogor, West Java Province. Glob. Adv. Res. J. Med. Med. Sci. 5(12): 289-291. [Online]. Available from https://www.researchgate.net/ publication/313248324_CTX-M-1_and_CTX-M-55_Producing Escherichia_coli_Isolated_from_Broiler_Feces_in_Poultry_ Slaughterhouse_Bogor_West_Java_Province\%0A. https:/ www.researchgate.net/publication/312662779.

Magiorakos, A.P., Srinivasan, A., Carey, R.B., Carmeli, Y., Falagas, M.E., Giske, C.G., et al. 2012. Multidrug-resistant, extensively drug-resistant and pandrug-resistant bacteria: an international expert proposal for interim standard definitions for acquired resistance. Clin. Microbiol. Infect. European Society of Clinical Infectious Diseases, 18(3): 268-281. doi:10.1111/j.1469-0691.2011.03570.x.

Maynard, C., Fairbrother, J.M., Bekal, S., Sanschagrin, F., Levesque, R.C., Brousseau, R., et al. 2003. Antimicrobial resistance genes in enterotoxigenic Escherichia coli O149: K91 isolates obtained over a 23-year period from pigs. Antimicrob. Agents Chemother. 47(10): 3214-3221. doi:10.1128/AAC.47.10. 3214-3221.2003. PMID:14506033.

Minarini, L.A.R., Poirel, L., Cattoir, V., Darini, A.L.C., and Nordmann, P. 2008. Plasmid-mediated quinolone resistance determinants among enterobacterial isolates from outpatients in Brazil. J. Antimicrob. Chemother. 62(3): 474-478. doi:10.1093/jac/dkn237.

Ministry of Agriculture Food and Rural Affairs. 2013. Regulations on the designation of animal medicines subject to prescription] (in Korean). [Online]. Available from https://www.law.go.kr/ admRulLsInfoP.do?admRulSeq=2000000092583.

Mohamed, M.A., Shehata, M.A., and Rafeek, E. 2014. Virulence genes content and antimicrobial resistance in Escherichia coli from broiler chickens. Vet. Med. Int. 2014: 1. doi:10.1155/ 2014/195189.

Musgrove, M.T., Jones, D.R., Northcutt, J.K., Cox, N.A., Harrison, M.A., Fedorka-Cray, P.J., and Ladely, S.R. 2006. Antimicrobial resistance in Salmonella and Escherichia coli isolated from commercial shell eggs. Poult. Sci. Poultry Science Association Inc., 85(9): 1665-1669. doi:10.1093/ps/85.9.1665.

Nilsson, O., Börjesson, S., Landén, A., and Bengtsson, B. 2014. Vertical transmission of Escherichia coli carrying plasmidmediated AmpC (pAmpC) through the broiler production pyramid. J. Antimicrob. Chemother. Oxford University Press, 69(6): 1497-1500. doi:10.1093/jac/dku030.

Osman, K.M., 2018. Poultry hatcheries as potential reservoirs for antimicrobial-resistant Escherichia coli: a risk to public health and food safety. Sci. Rep. Springer US, 8(1): 1-14. doi:10.1038/s41598-018-23962-7.

Park, H., Kappell, A.D., Elhadidy, M., ElMougy, F., Abd El-Ghany, W.A., Orabi, A., et al. 2019. Predominance of bla CTX-M-65 and bla CTX-M-55 in extended-spectrum $\beta$-lactamase-producing Escherichia coli from raw retail chicken in South Korea. J. Glob. Antimicrob. Resist. 17: 216-220. doi:10.1016/ j.jgar.2019.01.005. PMID:30658198.

Parvin, M.S., Talukder, S., Ali, Y., Chowdhury, E.H., Rahman, T., and Islam, T. 2020. Antimicrobial resistance pattern of Escherichia coli isolated from frozen chicken meat in Bangladesh. Pathogens 9(6): 420. doi:10.3390/pathogens9060420.

Petersen, A., Christensen, J.P., Kuhnert, P., Bisgaard, M., and Olsen, J.E. 2006. Vertical transmission of a fluoroquinoloneresistant Escherichia coli within an integrated broiler operation. Vet. Microbiol. 116(1-3): 120-128. doi:10.1016/ j.vetmic.2006.03.015. PMID:16650662.

Pitout, J.D.D., Hossain, A., and Hanson, N.D. 2004. Phenotypic and Molecular Detection of CTX-M-beta-Lactamases produced by Escherichia coli and Klebsiella spp. J. Clin. Microbiol. 42(12): 5715-5721. doi:10.1128/JCM.42.12.5715-5721.2004. PMID:15583304.

Poirel, L., Madec, J.-Y., Lupo, A., Schink, A.-K., Kieffer, N., Nordmann, P., and Schwarz, S. 2018. Antimicrobial resistance in Escherichia coli. Microbiol. Spectr. 6(4). doi:10.1128/ microbiolspec.ARBA-0026-2017.

Rao, L., Lv, L., Zeng, Z., Chen, S., He, D., and Chen, X. 2014. Increasing prevalence of extended-spectrum cephalosporinresistant Escherichia coli in food animals and the diversity of CTX-M genotypes during 2003-2012. Vet. Microbiol. Elsevier B.V., 172(3-4): 534-541. doi:10.1016/j.vetmic.2014. 06.013.

Roberts, M.C. 1996. Tetracycline resistance determinants: mechanisms of action, regulation of expression, genetic mobility, and distribution. FEMS Microbiol. Rev. 19(1): 1-24. doi:10.1111/j.1574-6976.1996.tb00251.x. PMID:8916553.

Roth, N., Hofacre, C., Zitz, U., Mathis, G.F., Moder, K., Doupovec, B., Berghouse, R., and Domig, K.J. 2019. Prevalence of antibiotic-resistant E. coli in broilers challenged with a multiresistant E. coli strain and received ampicillin, an organic acid-based feed additive or a synbiotic preparation. Poult. Sci. 98(6): 2598-2607. doi:10.3382/ps/pez004. PMID:30690607.

Sandvang, D., and Aarestrup, F.M. 2000. Characterization of aminoglycoside resistance genes and class 1 integrons in porcine and bovine gentamicin-resistant Escherichia coli. Microb. Drug Resist. 6(1): 19-27. doi:10.1089/mdr.2000.6.19. PMID:10868804.

Sandvang, D., Aarestrup, F.M., and Jensen, L.B. 1998. Characterisation of integrons and antibiotic resistance genes in Danish multiresistant Salmonella enterica Typhimurium 
DT104. FEMS Microbiol. Lett. 160(1): 37-41. doi:10.1111/j.15746968.1998.tb12887.x. PMID:9495010.

Sary, K., Fairbrother, J.M., Arsenault, J., de Lagarde, M., and Boulianne, M. 2019. Antimicrobial resistance and virulence gene profiles among Escherichia coli Isolates from retail chicken carcasses in vietnam. Foodborne Pathog. Dis. 16(4): 298-306. doi:10.1089/fpd.2018.2555. PMID:30767657.

Seifi, S., and Khoshbakht, R. 2016. Prevalence of tetracycline resistance determinants in broiler isolated Escherichia coli in Iran. Br. Poult. Sci. Taylor \& Francis, 57(6): 729-733. doi:10.1080/00071668.2016.1232478.

Sengeløv, G., Halling-Sørensen, B., and Aarestrup, F.M. 2003. Susceptibility of Escherichia coli and Enterococcus faecium isolated from pigs and broiler chickens to tetracycline degradation products and distribution of tetracycline resistance determinants in E. coli from food animals. Vet. Microbiol. 95: 91-101. doi:10.1016/S0378-1135(03)00123-8. PMID:12860079.

Seo, K.W., and Lee, Y.J. 2020. Prevalence and characterization of plasmid-mediated quinolone resistance determinants $q n r$ and $a a c\left(6^{\prime}\right)-I b-c r$ in ciprofloxacin-resistant Escherichia coli isolates from commercial layer in Korea. J. Microbiol. Biotechnol. 30(8): 1180-1183. doi:10.4014/jmb.2003.03058. PMID:32423191.

Seo, K.W., Shim, J.B., and Lee, Y.J. 2019. 'Comparative genetic characterization of third-generation cephalosporin-resistant Escherichia coli isolated from a layer operation system in Korea. Poult. Sci. 2018 Poultry Science Association Inc., 98(3): 1472-1479. doi:10.3382/ps/pey513.
Szmolka, A., and Nagy, B. 2013. Multidrug resistant commensal Escherichia coli in animals and its impact for public health. Front. Microbiol. 4: 1-13. doi:10.3389/fmicb.2013.00258.

U.S. Department of Agriculture. 2014. National poultry improvement plan and auxiliary provisions. APHIS publication, Washington, DC.

Van, T.T.H., Chin, J., Chapman, T., Tran, L.T., and Coloe, P.J. 2008. Safety of raw meat and shellfish in vietnam: an analysis of Escherichia coli isolations for antibiotic resistance and virulence genes. Int. J. Food Microbiol. 124(3): 217-223. doi:10.1016/j.ijfoodmicro.2008.03.029. PMID:18457892.

Wang, J., Ma, Z.-B., Zeng, Z.-L., Yang, X.-W., Huang, Y., and Liu, J.-H. 2017. The role of wildlife (wild birds) in the global transmission of antimicrobial resistance genes. Zool. Res. 38(2): 55-80. doi:10.24272/j.issn.2095-8137.2017.003. PMID:28409502.

Wang, M., Tran, J.H., Jacoby, G.A., Zhang, Y., Wang, F., and Hooper, D.C. 2003. Plasmid-mediated quinolone resistance in clinical isolates of Escherichia coli from Shanghai, China. Antimicrob. Agents Chemother. 47(7): 2242-2248. doi:10.1128/AAC.47.7.2242-2248.2003. PMID:12821475.

World Health Organization. 2018. Critically important antimicrobials (CIA), 6th revision. Geneva. [Online]. Available from https://www.who.int/publications/i/item/9789241515528.

World Organisation for Animal Health (OIE). 2018. OIE list of antimicrobial agents of veterinary importance. Geneva, Switzerland. [Online]. Available from http://www.oie.int/ fileadmin/Home/eng/Our_scientific_expertise/docs/pdf/AMR/ A_OIE_List_antimicrobials_May2018.pdf. 